\section{Synthesis of Omarigliptin}<smiles>C#CCC(NC(C)(C)C)C(=O)N(C)OC</smiles>

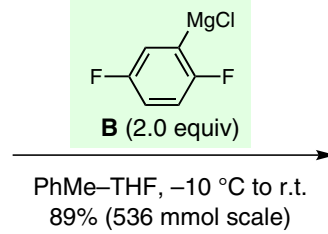

mp not reported<smiles>C#CCC(NC(C)(C)C)C(=O)c1cc(F)ccc1F</smiles>
mp not reported

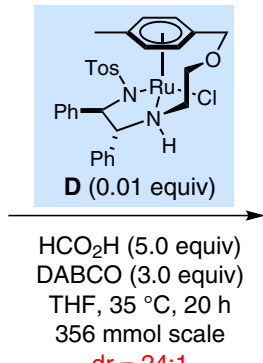
$\mathrm{dr}=24: 1$<smiles>C#CC[C@H](O)[C@H](O)c1cc(F)ccc1F</smiles>

E

Gategory

Synthesis of Natural

Products and

Potential Drugs

\section{Key words}

omarigliptin

dipeptidyl

dipeptidase-4

inhibitor

dynamic kinetic

resolution

asymmetric transfer

hydrogenation

ruthenium catalysis

cycloisomerization<smiles>CC(C)(C)OC(=O)NC1CC=CO[C@H]1c1cc(F)ccc1F</smiles>

$\mathrm{BH}_{3} \cdot \mathrm{SMe}_{2}$ (2.5 equiv) MTBE, $0{ }^{\circ} \mathrm{C}$;

$\mathrm{NaBO}_{3} \cdot 4 \mathrm{H}_{2} \mathrm{O}$ (3.0 equiv)

MTBE- $\mathrm{H}_{2} \mathrm{O}$, r.t.

G

$89 \%$ (321 $\mathrm{mmol}$ scale)

$\mathrm{RuCl}_{3}$ (0.005 equiv)

$\mathrm{NaBrO}_{3}$ (0.6 equiv)

$\mathrm{MeCN}-\mathrm{AcOH}-\mathrm{H}_{2} \mathrm{O}, 0{ }^{\circ} \mathrm{C}$

$89 \%(273 \mathrm{mmol})$<smiles>CC(C)(C)OC(=O)NC1CC(=O)CO[C@H]1c1cc(F)ccc1F</smiles>

H

mp not reported

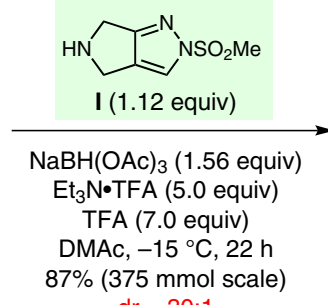

$d r=30: 1$
$\mathrm{CpRuCl}\left(\mathrm{PPh}_{3}\right)_{2}$ (0.02 equiv) $\mathrm{Ph}_{3} \mathrm{P}(0.06$ equiv)

$\mathrm{N}$-hydroxysuccinimide ( 0.5 equiv)

$\mathrm{Bu}_{4} \mathrm{NPF}_{6}$ ( 0.13 equiv)

$\mathrm{NaHCO}_{3}$ ( 0.5 equiv)

DMF, $80^{\circ} \mathrm{C}, 16 \mathrm{~h}$

$80 \%$ from C mp not reported
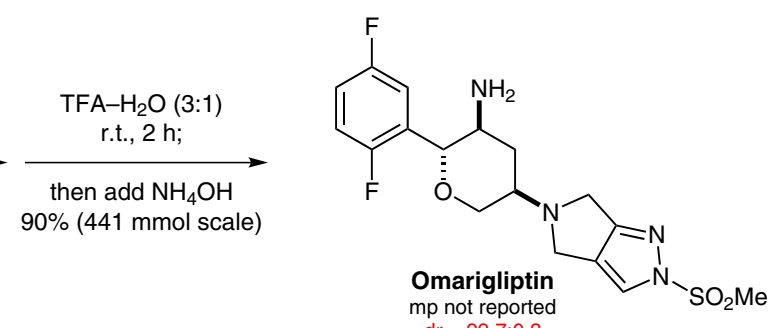

$\mathrm{mp}$ not reported
Significance: Omarigliptin (MK-3102) is a dipeptidyl peptidase-4 (DPP-4) inhibitor that has received marketing authorization in Japan for the onceweekly treatment of type 2 diabetes. The synthesis of pyranone $\mathbf{H}$ depicted features three ruthenium-catalyzed reactions: (1) a DKR reduction of rac- $\alpha$-aminoketone $\mathbf{C}$ to set the two contiguous stereogenic centers, (2) a cycloisomerization of alkyne $\mathbf{E}$ to dihydropyran $\mathbf{F}$, and (3) a rutheniumcatalyzed oxidation of pyranol $\mathbf{G}$ to the desired pyranone $\mathbf{H}$.
Comment: The Takasago tethered ruthenium(II) catalyst $\mathbf{D}$ is a highly efficient asymmetric transfer hydrogenation catalyst. The catalyst loading was reduced to $0.1 \mathrm{~mol} \%$ without sacrificing selectivity and reaction kinetics. It was critical to apply efficient $\mathrm{N}_{2}$ sparging during the reaction to remove $\mathrm{CO}_{2}$; otherwise, the reaction could stall if this was allowed to accumulate. For the discovery synthesis of omarigliptin, see: T. Biftu et al. J. Med.

Chem. 2014, 57, 3205.

SYNFACTS Contributors: Philip Kocienski 